\title{
Runt-Related Transcription Factor 2
}

National Cancer Institute

\section{Source}

National Cancer Institute. Runt-Related Transcription Factor 2. NCI Thesaurus. Code C91787.

Runt-related transcription factor 2 ( $521 \mathrm{aa}, \sim 57 \mathrm{kDa}$ ) is encoded by the human RUNX2 gene. This protein plays a role in the regulation of both bone development and transcription. 